Vol 4. No 1. Februari 2020

ISSN 2580-5029

\title{
ANALISIS VEGETASI DI KAWASAN PETILASAN MBAH MARIDJAN TAMAN NASIONAL GUNUNG MERAPI
}

\author{
Amri Shabirin ${ }^{1 *}$, Yuliantika Puteri ${ }^{1}$, Hendrianis Syafira ${ }^{1}$, Tia Mayasari ${ }^{1}$, Mufti Nurkhasanah $^{1}$ \\ 1Jurusan Pendidikan Biologi Universitas Negeri Yogyakarta, Yogyakarta, Indonesia \\ *Email: amrishabirin.2018@student.uny.ac.id
}

\begin{abstract}
This research aims to determine the diversity of habitus and species that dominate in the region of Kinahrejo, Umbulharjo, Cangkringan, Sleman. The method used is square sampling by making a $7 \times 7$ meters square plot of 2 plots so that an area of $98 \mathrm{~m}^{2}$ is obtained. Vegetation analysis using the method of observation, and monitoring (field observation) directly with random sampling and using the principle of representative. Analysis the level of habitat diversity using the Shannonwienner Index and determination of species that dominate using the calculation of the Important Value Index (INP). A total of 34 species consisting of mosses, shrubs, herbs, and stand-structure are occupy the observation area. The results of the research and analysis showed that Tamarindus indica, which included stand-structure habitus had the highest INP of 139.54\% and the lowest INP was found in shrubs habitus. The highest Shannon-wienner index in shrubs habitus is 1.220928 and the lowest is in stand-structure habitus. It can be concluded, stand-structure habitus dominates the area while, the highest diversity is found in shurbs habitus. The eruption in 2010 caused damage to ecosystems and invasive plants to become dominant such as Acacia decurrens and shrubs.
\end{abstract}

Keywords: Vegetation Analysis, Taman Nasional Gunung Merapi

\begin{abstract}
ABSTRAK
Penelitian ini bertujuan untuk mengetahui keanekaragaman habitus dan spesies yang mendominasi di wilayah Kinahrejo, Umbulharjo, Cangkringan, Sleman. Metode yang digunakan adalah square sampling dengan membuat petak persegi berukuran $7 \mathrm{x} 7$ meter sebanyak 2 plot sehingga didapatkan luas area $98 \mathrm{~m}^{2}$. Analisis vegetasi menggunakan metode pengamatan, dan pemantauan (observasi lapangan) secara langsung dengan random sampling dan menggunakan prinsip representatif. Perhitungan tingkat keanekaragaman habitus menggunakan Indeks Shannon-wienner, dan penentuan spesies yang mendominasi menggunakan perhitungan Indeks Nilai Penting (INP). Ada sejumlah 34 spesies yang terdiri dari lumut, semak, herba, dan tegakkan mendiami kawasan pengamatan. Hasil penelitian dan analisis menunjukkan Tamarindus indica yang termasuk habitus tegakkan memiliki INP tertinggi sebesar 139,54\% dan INP terendah terdapat pada habitus semak. Indeks Shannon-wienner tertinggi pada habitus semak sebesar 1,220928 dan terendah pada habitus tegakkan. Dapat disimpulkan, habitus tegakkan mendominasi daerah tersebut sedangkan keanekaragaman tertinggi terdapat pada habitus semak. Erupsi pada 2010 menyebabkan kerusakan ekosistem dan tumbuhan invasif menjadi dominan seperti Acacia decurrens serta semak.
\end{abstract}

Kata kunci: Analisis Vegetasi, Taman Nasional Gunung Merapi 


\section{PENDAHULUAN}

Perkembangan sains di zaman modern atau era Revolusi Industri 4.0, khususnya bidang seputar biologi, tidak bisa lepas dari pengaruh perubahan kondisi alam semesta yang bersifat komplementer dan kompreherensif antara suatu peristiwa dengan peristiwa lain dalam suatu dimensi ruang dan waktu tertentu. Hal ini juga sejalan dengan cara pandang dan sikap manusia terhadap alam yang semakin maju kondisi zaman membuat manusia kurang begitu memelihara, tetapi merusak lingkungan alam sekitar sehingga mengakibatkan terjadinya ketidakseimbangan ekosistem. (Subiantoro \& Handziko, 2011)

Gunung Merapi memiliki ketinggian 2.968 meter di atas permukaan laut (mdpl) merupakan salah satu diantara gunung berapi aktif di Indonesia dan merupakan dan termasuk dalam deretan Ring of Fire yang terletak di sisi selatan kepulauan Nusantara (Pulau Jawa). Lereng sisi selatan berada dalam administrasi Kabupaten Sleman, Daerah Istimewa Yogyakarta, dan sisanya berada dalam wilayah Provinsi Jawa Tengah, yaitu Kabupaten Magelang di sisi barat, Kabupaten Boyolali di sisi utara dan timur, serta Kabupaten Klaten di sisi tenggara. Kawasan hutan di sekitar puncaknya menjadi kawasan Taman Nasional Gunung Merapi sejak tahun 2004.(Subiantoro \& Handziko, 2011)

Gunung Merapi secara berkala mengalami erupsi seperti yang terjadi pada tahun 2006 dan 2010. Erupsi Gunung Merapi yang terjadi pada Oktober 2010 merupakan erupsi terbesar yang pernah terjadi pada Gunung Merapi. Erupsi ini memberikan dampak langsung terhadap lingkungan di sekitar Gunung Merapi berupa kerusakan ekosistem yang disebabkan oleh lahar, awan panas dan debu vulkanik dalam jumlah yang sangat besar (Wismaya, Anjasmara, \& Sulistiyani, 2016) serta memberikan pengaruh terhadap ekosistem hutan di daerah tersebut dan juga terjadinya suksesi. Hutan sendiri merupakan suatu kumpulan tumbuhan, terutama tumbuhan berkayu yang menaungi kawasan yang luas. Hutan memiliki fungsi sebagai ekosistem yaitu penyedia sumber air, penghasil oksigen, tempat bernaung flora dan fauna, penyeimbang lingkungan, dan mencegah pemanasan global. (Natalia \& Handayani, 2013)

Struktur dan komposisi vegetasi tumbuhan dipengaruhi oleh komponen ekosistem lainnya yang saling berinteraksi sehingga vegetasi yang tumbuh secara alami merupakan hasil interaksi berbagai faktor lingkungan. Struktur vegetasi adalah suatu organisasi individu-individu di dalam ruang yang membentuk suatu tegakan, sedangkan komposisi hutan merupakan jenis-jenis penyusun yang menempati vegetasi di suatu tempat. (Destaranti, Sulistyani, \& Yani, 2017)

Analisis vegetasi terhadap hutan perlu dilakukan untuk mengetahui keanekaragaman hayati yang terdapat di hutan tersebut sehingga mempermudah 
didalam melakukan pemeliharaan dan pemberdayaan hutan. Untuk keperluan analisis vegetasi diperlukan data jenis tumbuhan, diameter, dan tinggi untuk menentukan indeks nilai penting dari penyusunan komunitas hutan tersebut. Dengan adanya analisis vegetasi dapat diperoleh informasi kuantitatif tentang struktur dan komposisi suatu ekosistem. (Munawwaroh, 2016)

Penelitian dilakukan di sekitar daerah kawasan Petilasan Mbah Maridjan Kinahrejo, Umbulharjo, Cangkringan, Sleman. Karakteristik tumbuhan sangat didominasi oleh vegetasi lantai. Vegetasi lantai adalah istilah bagi spesies tumbuhan penyusun vegetasi (hutan) yang tumbuh di bawah tutupan pohon dominan. Vegetasi lantai terdiri atas tumbuhan dengan bentuk hidup semak, herba, dan rumput. Vegetasi lantai memiliki peran penting memberi sumbangan penting bagi keseimbangan sebuah ekositem, sebagai sumber hara habitat, habitat bagi serangga, burung, dan mamalia, dan kelimpahan serta komposisinya mempengaruhi beberapa proses ekologis, termasuk kebakaran dan erosi. (Natalia \& Handayani, 2013)

Tujuan dari penelitian ini adalah untuk mengetahui jenis dan habitus tumbuhan yang terdapat di lokasi pengamatan, mengetahui indeks nilai penting pada masing-masing habitus serta tingkat keanekaragaman hayati di setiap habitus, sehingga di akhir penelitian kami dapat mengetahui spesies dan habitus yang mendominasi di daerah tersebut dan mengetahui dampak adanya erupsi gunung Merapi terhadap keanekaragaman hayati.

\section{METODE}

\section{Waktu dan Tempat Penelitian}

Penelitian ini dilakukan pada bulan Oktober sampai November tahun 2019. Pengambilan data dilaksanakan di Kawasan Taman Nasional Gunung Merapi, tepatnya di Dusun Kinahrejo, Kec. Cangkringan, Kab. Sleman, DIY. Identifikasi tanaman, dan pengolahan data dilakukan di Laboratorium Fakultas Matematika dan Ilmu Pengetahuan Alam (FMIPA) Universitas Negeri Yogyakarta.

\section{Alat dan bahan \\ Alat yang digunakan dalam penelitian ini terdiri dari thermometer, lux meter, anemometer, hygrometer, soil tester, meteran, kamera handphone, tali rafia, patok, gunting, dan alat tulis. Bahan yang digunakan dalam penelitian ini adalah vegetasi tumbuhan di lokasi Taman Nasional Gunung Merapi Dusun Kinahrejo.}

\section{Metode}

Dalam penelitian ini dilakukan analisis vegetasi dengan pembuatan petak kuadrat ukuran $7 \times 7 \mathrm{~m}$ sebanyak 2 kali sehingga dihasilkan luas area sejumlah $98 \mathrm{~m}^{2}$. Metode Analisis vegetasi yang digunakan dalam penelitian ini adalah pengamatan, dan pemantauan (observasi lapangan) secara langsung dengan random sampling dan 
menggunakan prinsip representative. Jenisjenis dan persentase penutupan kanopi setiap jenis tumbuhan yang ada di tiap plot dicatat. Kondisi lingkungan berupa suhu udara, kelembapan, kecepatan angin dan intensitas cahaya di setiap plot diukur menggunakan alat ukur edafik.

\section{Struktur}

Perhitungan struktur vegetasi meliputi frekuensi, dominansi, densitas, dan nilai penting dari masing-masing jenis. Selanjutnya tingkat keanekaragaman jenis tumbuhan dihitungn dengan menggunakan analisis indeks keanekaragaman ShannonWienner.

\section{Shannon Index: $\mathrm{H}^{\top}$}

$H^{\prime}=-\sum_{i=1}^{S} \quad p i \ln p i$

(Ermawan, Ikmat, \& Artono, 2016)

\section{HASIL DAN PEMBAHASAN (11 pt)}

Indeks Nilai Penting (INP) dapat digunakan untuk mengetahui dominansi spesies dalam komunitas tumbuhan yang diteliti. Indeks Nilai Penting (INP) digunakan sebagai besaran yang menunjukkan kedudukan suatu jenis terhadap jenis lain dalam suatu komunitas. Makin besar INP suatu jenis, maka peranannya dalam komunitas tersebut semakin penting. (Marpaung, 2016)

Berdasarkan observasi yang dilakukan pada Jum'at, 11 Oktober 2019 di Kinahrejo, Umbulharjo, Sleman, Yogyakarta ditemukan terdapat 33 spesies tanaman dengan rincian
3 jenis lumut, 4 jenis herba, 3 jenis tegakan, dan 23 jenis semak (tabel 1 ).

Tabel 1. Daftar spesies yang ditemukan.

\begin{tabular}{|c|c|c|}
\hline Habitus & Jenis & $\begin{array}{c}\text { Jumlah } \\
\text { Individu }\end{array}$ \\
\hline \multirow{3}{*}{ Lumut } & Parmelia saxatilis & 16 \\
\hline & Dricanella subulata & 5 \\
\hline & Salix alba L. & 4 \\
\hline \multirow[t]{4}{*}{ Herba } & Anaphalis javanica & 6 \\
\hline & Sorgum halepense & 1 \\
\hline & Cyantea borbonica & 1 \\
\hline & Dryopteris marginalis & 2 \\
\hline \multirow[t]{3}{*}{ Tegakan } & Tamarindus indica & 1 \\
\hline & Psidium guajava & 1 \\
\hline & Persicaria capitata & 10 \\
\hline \multirow[t]{24}{*}{ Semak } & Agrimonia eupatoria & 1 \\
\hline & kelas Poaceae & 6 \\
\hline & Cornus canandensis & 1 \\
\hline & Oxalis curniculata & 1 \\
\hline & Smilax aspera & 2 \\
\hline & Amorpha fusticosa & 1 \\
\hline & Ageratina riparia & 7 \\
\hline & Vinca major & 2 \\
\hline & Hypoestes phyllostachya & 3 \\
\hline & Phaseolus vulgaris & 5 \\
\hline & Lonicera japonica & 1 \\
\hline & Erigon canadensis & 2 \\
\hline & Lantana camara & 2 \\
\hline & Anaphalis longifolia & 4 \\
\hline & Althernantera & 5 \\
\hline & brasiliana & \\
\hline & Eupotarium inuliforium & 4 \\
\hline & Caltha palustris & 2 \\
\hline & Cynodon dactilon & 54 \\
\hline & Athyrium filix-femina $L$ & 43 \\
\hline & Carex pendula & 1 \\
\hline & $\begin{array}{l}\text { Melastoma } \\
\text { malabathricum }\end{array}$ & 5 \\
\hline & Phytoacca americana & 1 \\
\hline & Trema tomentosa & 1 \\
\hline
\end{tabular}

Faktor-faktor lingkungan sangat berpengaruh terhadap vegetasi diantaranya adalah ketinggian tempat, kelembaban udara, suhu udara, serta intensitas cahaya matahari. Faktor-faktor tersebut berpengaruh terhadap penyebaran jenis-jenis tumbuhan dan persebaran.(Destaranti et al., 2017) 
Indeks nilai penting (INP) menunjukkan peranan jenis tersebut di dalam suatu kawasan. Jenis yang mempunyai INP paling besar berati mempunyai pengaruh paling dominan terhadap perubahan kondisi lingkungan maupun keberadaan jenis lainnya dalam kawasan tersebut. Jenis-jenis yang memiliki peranan besar pada suatu komunitas dicirikan oleh nilai penting yang tinggi karena merupakan penjumlahan dari Kerapatan Relatif (KR), Frekuensi Relatif (FR), dan Dominansi Relatif (DR).(Zefry Arqino Ginting, Togar Renando Manurung, 2017)

Makin besar INP suatu jenis, maka peranannya dalam komunitas tersebut semakin penting. Sifat mendominasi suatu jenis tertentu dapat menimbulkan dampak buruk bagi ekosistem yang menempati jenis tersebut. (Zulkarnain, Kasim, \& Hamid, 2015)

Invasi adalah suatu sifat yang menggambarkan kinerja suatu spesies tumbuhan atau hewan yang menjadi dominan serta mengancam ekosistem, habitat, dan spesies yang terdapat di lokasi. perbedaan struktur dan komposisi pada setiap strata tumbuhan bawah berkaitan erat dengan kondisi habitat. Faktor lingkungan yang mempengaruhi pertumbuhan adalah ketinggian tempat diatas permukaan laut. Ketinggian tempat akan mempengaruhi kekayaan jenis, struktur, dan komposisi vegetasi tumbuhan bawah, keadaan tanah, suhu, intensitas cahaya matahari, serta air. Secara tidak langsung, ketinggian tempat akan berpengaruh pada proses fotosintesis serta akan menjadi faktor pembatas yang menekan pertumbuhan tumbuhan bawah. (Destaranti et al., 2017)

Tabel 2. Indeks Nilai Penting pada setiap habitus

\begin{tabular}{llcl}
\hline Habitus & Spesies & \multicolumn{1}{c}{ INP } & Keterangan \\
\hline Lumut & $\begin{array}{l}\text { Dricanella } \\
\text { subulata } \\
\text { Semak }\end{array}$ & $136,46 \%$ & Tertinggi \\
& $\begin{array}{l}\text { Salixalba L. } \\
\text { Cynodon } \\
\text { dactilon } \\
\text { Herba }\end{array}$ & $59,68 \%$ & Terendah \\
& $\begin{array}{l}\text { Agrimonia } \\
\text { eupatoria }\end{array}$ & $4,83 \%$ & Tertinggi \\
& $\begin{array}{l}\text { Anaphalis } \\
\text { javanica }\end{array}$ & $107,93 \%$ & Terendah \\
& $\begin{array}{l}\text { Sorgum } \\
\text { Talepense } \\
\text { Tegakan }\end{array}$ & $35,39 \%$ & Terendah \\
& $\begin{array}{l}\text { Tamarindus } \\
\text { indica } \\
\text { Psidium } \\
\text { guajava }\end{array}$ & $139,54 \%$ & Tertinggi \\
& $42,05 \%$ & Terendah \\
\hline
\end{tabular}

Berdasarkan tabel 2, Indeks nilai penting tertinggi pada tingkat lumut ditemukan pada spesies Dricanella subulata dengan nilai $136,46 \%$ sedangkan nilai penting terendah ditemukan pada spesies Salix alba $L$ dengan nilai 49,68\%. Pada tingkat herba nilai penting terbesar terdapat pada spesies Dryopteris marginalis dengan nilai $118,40 \%$ dan terendah pada Sorgum halepense yaitu sebesar 35,39\% pada tingkatan tegakan INP tertinggi terdapat pada Tamarindus indica yaitu sebesar 139,54\% dan terendah terdapat pada spesies Psidium guajava sebesar 42,05\%. sedangkan pada tingkat semak INP tertinggi terdapat pada spesies Cynodon dactilon sebesar 57,38\% dan INP terendah untuk tingkat semak adalah spesies Agrimonia eupatoria sebesar 4,83\%. jenis yang memiliki indeks nilai penting tertinggi 
adalah jenis yang dominan. Hal ini mencerminkan tingginya kemampuan jenis tersebut untuk menyesuaikan diri pada lingkungannya dan dapat bersaing terhadap jenis lainnya.(Destaranti et al., 2017)

Selanjutnya vegetasi dengan kemampuan penyebaran paling luas pada lokasi studi adalah spesies dengan nilai tertinggi seperti pada Dricanella subulata pada habitus semak, Dryopteris marginalis pada habitus herba, Tamarindus indica pada habitus tegakan, dan Cynodon dactilon pada habitus semak. Jenis- jenis tersebut merupakan jenis dengan nilai frekuensi tertinggi pada setiap tingkat vegetasi, yang mengindikasikan kemampuan persebaran yang paling baik dibandingkan jenis yang lain. Hal ini terjadi karena faktor edafik seperti intensitas penyinaran matahari, suhu, pH tanah yang mendukung spesies-spesies tersebut untuk tumbuh.

Berdasarkan data diperoleh hasil yaitu INP tertinggi di stasiun pengamatan terdapat pada spesies Tamarincus indica sebesar $139,54 \%$ yaitu terdapat pada habitus tegakan. Secara umum tumbuhan dengan nilai INP yang tinggi mempunyai daya adaptasi, daya kompetisi, dan kemampuan reproduksi yang lebih baik dibandingkan dengan tumbuhan yang lain dalam satu lahan tertentu.

Tamarindus indica sesuai dibudidayakan di daerah tropis, tanaman ini bisa hidup di tempat yang suhu udaranya sekitar $45^{\circ} \mathrm{C}$, dapat tumbuh di kisaran tipe tanah yang luas dan perawatannya tidak terlalu rumit. Tamarindus indica atau disebut juga asam jawa termasuk jenis tanaman yang memiliki akar yang bisa mencapai tanah cukup dalam, tahan terhadap kekeringan dan angin kencang, dan menghasilkan buah yang banyak jika hidupnya di daerah dengan periode kering yang cukup panjang. Asam jawa juga merupakan tanaman meliar yang tumbuh di hutan-hutan dan savana. Pohon ini dapat tumbuh baik hingga ketinggian $1.000 \mathrm{~m}$ - 1.500 mdpl, pada tanah berpasir atau tanah liat, khususnya di wilayah yang musim keringnya jelas dan cukup panjang.(Setiawan, 2018)

Adapun hasil pengukuran klimatik dan edafik pada area pengamatan didapatkan data sebagai berikut :

Tabel 3. Data abiotik edafik

\begin{tabular}{ll}
\hline Parameter & Nilai / hasil \\
\hline $\begin{array}{l}\text { Intensitas cahaya matahari ( } \\
\text { dibawah naungan) }\end{array}$ & $4100 \mathrm{Cd}$ \\
$\begin{array}{l}\text { Intensitas cahaya matahari } \\
\text { (terpapar sinar matahari }\end{array}$ & $6650 \mathrm{Cd}$ \\
langsung) & \\
Kecepatan angin & $1,8 \mathrm{~m} / \mathrm{s}$ \\
Suhu & $37,20 \mathrm{C}$ \\
pH tanah & 7 \\
kelembaban & $18 \%$ \\
Tekstur tanah & Kering dan \\
& berpasir \\
\hline
\end{tabular}

Salah satu faktor yang berpengaruh dalam kompetisi pertumbuhan tanaman adalah intensitas cahaya matahari. Peningkatan intensitas cahaya matahari meningkatkan proses fotosintesis pada tanaman, karena cahaya matahari merupakan sumber energi untuk fotosintesis. (Zulkarnain et al., 2015) 
Dari hasil pengukuran ini didapatkan hasil bahwa kondisi alam pada area pengamatan sangat mendukung pertumbuhan tanaman Tamarindus indica yaitu tekstur tanah yang kering dan berpasir, suhu udara yang panas, dan kelembaban tanah yang rendah sehingga tanaman tersebut memiliki nilai mutlak tertinggi atau paling mendominasi pada area pengamatan. Sedangkan INP terendah terdapat pada spesies Agrimonia eupatoriasebesar $4.81 \%$ dan terdapat pada habitus semak. Berdasarkan uraian diatas Agrimonia eupatoria tidak dapat tumbuh dengan baik karena kondisi lingkungan abiotik yang terukur berupa suhu tanah, intensitas cahaya, suhu udara, $\mathrm{pH}$ tanah dan kelembaban udara tidak sesuai dengan kondisi umum tumbuh, sehingga hanya sedikit persebaran ditemukan. Adapun Agrimonia eupatoria adalah tumbuhan yang dapat dengan mudah di peroleh di tempat kering dihutan dan ladang. (Cepeda et al., 2019).

Untuk menentukan tingkat keanekaragaman jenis tumbuhan menggunakan analisis indeks keanekaragaman Shannon- Wienner

Tabel 4. Data Indeks Shannon-Wienner

\begin{tabular}{ccc}
\hline No. & Jenis Habitus & Indeks Shannon \\
\hline 1. & Lumut & 0,444625 \\
2. & Semak & 1,220928 \\
3. & Herba & 0,64840753 \\
4. & Tegakkan & 0,4335836 \\
\hline
\end{tabular}

Pada lokasi pengamatan, Indeks Shannon tertinggi terdapat pada habitus Semak dan terendah berada pada habitus Tegakkan.
Hasil perhitungan ini mengindikasikan bahwa tingkat keanekaragaman tertinggi pada daerah pengamatan adalah habitus semak.

Erupsi Gunung Merapi pada Oktober 2010 merupakan erupsi terbesar (Surono et al., 2012) dan telah mengakibatkan kerusakan ekosistem sangat parah yang disebabkan oleh lahar, awan panas, dan debu vulkanik. Erupsi 2010 telah menyebabkan spesies invasif menjadi dominan pada area-area yang terkena erupsi berat, yang sangat didominasi oleh Acacia decurrens yang berasosiasi dengan E. riparium.(Afrianto et al., 2016) selain itu tumbuhan bawah yang mendominasi di hampir seluruh kawasan Gunung Merapi setelah erupsi 2010. Hasil penelitian ini sesuai dengan Sutomo \& Fardila (2013), yang melaporkan bahwa E. riparium merupakan spesies yang mendominasi di area yang terkena dampak erupsi sangat parah di Kalikuning. (Sutomo \& Fardila, 2013)

\section{KESIMPULAN}

Berdasarkan penelitian yang telah dilakukan di Kawasan Taman Nasional Gunung Merapi dapat disipulkan bahwa:

1. Terdapat 34 spesies tanaman dengan rincian 3 jenis lumut, 4 jenis herba, 3 jenis tegakan, dan 24 jenis semak.

2. Indeks nilai penting tertinggi pada habitus lumut ditemukan pada spesies Dricanella subulata dengan nilai $136,46 \%$ sedangkan nilai penting 
terendah ditemukan pada spesies Salix alba $L$ dengan nilai $49,68 \%$. Pada tingkat herba nilai penting terbesar terdapat pada spesies Dryopteris marginalis dengan nilai $118,40 \%$ dan terendah pada Sorgum halepense yaitu sebesar $35,39 \%$. pada tingkatan tegakan nilai penting tertinggi terdapat pada Tamarindus indica yaitu sebesar 139,54\% dan terendah terdapat pada spesies Psidium guajava sebesar 42,05\%. sedangkan pada tingkat semak nilai penting tertinggi terdapat pada spesies Cynodon dactilon sebesar $57,38 \%$ dan INP terendah untuk tingkat semak adalah spesies Agrimonia eupatoria sebesar $4,83 \%$.

3. Indeks Shanon tertinggi pada lokasi pengamatan terdapat pada habitus semak dan terendah pada habitus tegakkan. Hal ini mengindikasikan bahwa semak memiliki keanekaragaman hayati yang tinggi dan tegakkan memiliki keanekaragaman jenis yang relatif lebih sedikit daripada habitus lainnya.

4. Erupsi Gunung Merapi pada tahun 2010 telah menyebabkan kerusakan ekosistem karena awan panas, lahar, dan debu vulkanik menyebabkan spesies invasif menjadi dominan seperti Acacia decurrens dan tumbuhan bawah seperti E. riparium dan berbagai habitus semak.

\section{DAFTAR PUSTAKA}

Afrianto, WF., Hikmat, A., Widyatmoko, D., Studi, P., Biodiversitas, K., Dramaga, K.,
No, HJ. 2016. Komunitas Floristik dan Suksesi Vegetasi Setelah Erupsi 2010 di Gunung Merapi Jawa Tengah ( Floristic Community and Vegetation Succession after the 2010 Eruption of Mount Merapi Central Jawa ). Jurnal Biologi Indonesia, 12(2), 265-276. https://doi.org/https://doi.org/10.142 03/jbi.v12i2.2895

Cepeda, G. N., Lisangan, M. M., Roreng, M. K., Permatasari, E. I., Manalu, D. C., \& Tanlain, W. (2019). Aktivitas Penangkalan Radikal Bebas dan Kemampuan Reduksi Ekstrak Kulit Kayu Akway (Drimys piperita Hook. f.). Jurnal Aplikasi Teknologi Pangan, 7(4), 168173.

https://doi.org/10.17728/jatp.3239

Destaranti, N., Sulistyani, S., \& Yani, E. (2017). Struktur Dan Vegetasi Tumbuhan Bawah Pada Tegakan Pinus Di Rph Kalirajut Dan Rph Baturraden Banyumas. Scripta Biologica, 4(3), 155. https://doi.org/10.20884/1.sb.2017.4.3 .407

Ermawan, R. U. D. I. H., Ikmat, A. G. U. S. H., \& Artono, A. G. U. S. P. K. (2016). ANALISIS FAKTOR EKOLOGI TUMBUHAN LANGKA ROTAN BEULA Ceratolobus glaucescens Blume DI CAGAR ALAM SUKAWAYANA SUKABUMI JAWA BARAT. Media Konservasi, 17(2), 94-110. https://doi.org/10.29243/medkon.17.2. $\% \mathrm{p}$

Marpaung, M. (2016). Analisis Vegetasi Tumbuhan Invasif di Kawasan Cagar Alam Lembah Anai, Sumatera Barat. Proceeding Biology Education Conference, 13(1), 2528-5742.

Munawwaroh, A. (2016). WONOSALAM JOMBANG PENDAHULUAN Hutan merupakan masyarakat tumbuhtumbuhan yang dikuasai oleh pohonpohon yang menempati suatu tempat dimana terdapat hubungan timbal balik antara tumbuhan tersebut dengan lingkunganya . Pepohonan yang tinggi sebagai komponen. Pedagogia, 5(1), 103-110. 
Natalia, D., \& Handayani, T. (2013). Analisis Vegetasi Strata Semak Di Plawangan Taman Nasional Gunung Merapi Pasca Erupsi Merapi 2010. Jurnal Bioedukatika, $1(1), \quad 62$. https://doi.org/10.26555/bioedukatika. v1i1.4095

Setiawan, E. (2018). Keragaman Populasi Pohon Asam (Tamarindus indica L.) di Jalan Raya Socah-Arosbaya, Kabupaten Bangkalan dan Strategi Konservasi. Rekayasa, 11(2), 95. https://doi.org/10.21107/rekayasa.v11 i2.4446

Subiantoro, A. W., \& Handziko, R. C. (2011). Erupsi Merapi Dan Potensi Pengembangan Bahan Ajar Biologi Berbasis Representasi. Seminar Nasional Biologi VIII, Prodi Pend. Biologi FKIP UNS, Tema: "Biologi, Sains, Lingkungan, Dan Pembelajarannya Menuju Pembangunan Karakter", Tanggal 16 Juli 2011. ISBN: 978-979-1533-23-2, 978979.

Surono, Jousset, P., Pallister, J., Boichu, M., Buongiorno, M. F., Budisantoso, A., ... Lavigne, F. (2012). The 2010 explosive eruption of Java's Merapi volcano-A "100-year" event. Journal of Volcanology and Geothermal Research. https://doi.org/10.1016/j.jvolgeores.20 12.06.018

Sutomo, S., \& Fardila, D. (2013). Floristic Composition of Groundcover Vegetation after the 2010 Pyroclastic Fire on Mount Merapi. Jurnal Manajemen Hutan Tropika (Journal of Tropical Forest Management).

https://doi.org/10.7226/jtfm.19.2.85

Wismaya, Y. G., Anjasmara, I. M., \& Sulistiyani, S. (2016). Analisis Deformasi Gunung Merapi Berdasarkan Data Pengamatan GPS Februari- Juli 2015. Jurnal Teknik ITS.

https://doi.org/10.12962/j23373539.v $5 \mathrm{i} 2.17226$

Zefry Arqino Ginting, Togar Renando Manurung, L. S. (2017). Analisis vegetasi pada kawasan hutan desa di desa nanga yen kecamatan hulu gurung kabupaten kapuas hulu. 5(3), 714-720.

Zulkarnain, Kasim, S., \& Hamid, H. (2015). Analisis Vegetasi Dan Visualisasi Struktur Vegetasi Hutan Kota Baruga, Kota Kendari. Hutan Tropis. 